\title{
HOSPITAL MORBIDITY IN EARLY LIFE IN RELATION TO CERTAIN MATERNAL AND FOETAL CHARACTERISTICS
} AND EVENTS AT DELIVERY

\author{
BY \\ E. D. ACHESON \\ Oxford Record Linkage Study, Nuffield Department of Clinical Medicine, University of Oxford
}

\begin{abstract}
Material AND Method
Using a system of linked medical records (Acheson, 1964), it is possible not only to accumulate and to correlate information about successive events as they occur to individuals, but to bring together information about different members of a family (Newcombe, Kennedy, Axford, and James, 1959; Newcombe, 1964). This study exemplifies a simple application of this approach in which information about two classes of individual related by blood (mothers and their babies) has been brought together from five separate categories of medical record for a defined population at risk.

An analysis has been made of the in-patient hospital morbidity experienced during 1962 of 5,901 babies born in that year to mothers resident at the time of delivery in the City of Oxford, Oxfordshire (except Henley Municipal Borough and Rural District Council), and Abingdon Municipal Borough and Rural District in Berkshire. This excludes 147 babies who were stillborn or who died before discharge from the maternity hospital in which they were born, and 379 babies who were born to resident mothers in hospitals outside the area for whom information about the relevant pregnancy and confinement were lacking. For the remainder, information was brought together from the following sources:
\end{abstract}

Baby: Birth certificate.

Hospital discharge summaries (if any).

Death certificate (if any).

Mother: Domiciliary confinement record (for mothers delivered at home).

OR

Hospital confinement record (for mothers delivered in hospital).

The records were checked with a master index to bring together different records relating to the same person, the birth certificate being used as a "bridge record" to collate the records of mother and baby.

A summary punched card was then prepared (Appendix A) relating to events in the calendar year 1962 only. The present paper deals with some simple analyses of the in-patient morbidity of the babies in relation to maternal characteristics and selected events at delivery.

$$
\text { IN-PATIENT MORBIDITY }=\frac{\begin{array}{l}
\text { No. of bables discharged from hos- } \\
\text { pital once or more in } 1962
\end{array}}{\begin{array}{l}
\text { Total No. of bables born allve who } \\
\text { were living on discharge from the } \\
\text { maternity hospital. }
\end{array}} \times 100 \text {. }
$$

It should be stressed that as the period of study was a calendar year the average period of exposure of the babies to the risk of admission to hospital is approximately 6 months, babies born on January 1 , 1962 , having a whole year's exposure, while at the other extreme for babies born on December 31, 1962, the exposure was nil. When the data of subsequent years is to hand it will be possible to take into account age at admission to hospital, and to consider separately for example the morbidity of the first month and of the remainder of the first year.

\section{General}

\section{RESULTS}

Diagnosis reached during First Spell of In-patient Care. -203 (3.4 per cent.) of the 5,901 babies were discharged from hospital in the calendar year 1962 once or more. Of these, 34 babies (16.7 per cent.) had been re-admitted or transferred at least once during the calendar year, the accumulated number of in-patient spells of treatment being 255 . In Table I (opposite) the 203 babies are distributed by principal diagnoses reached during the first hospital spell grouped according to the major divisions of the International Statistical Classification of Diseases, Injuries, and Causes of Death (WHO, 1957). 
As was expected, the largest single cause of admission (29.0 per cent.) was a congenital malformation. The other large groups were digestive and genitourinary diseases (14.8 per cent.), diseases peculiar to infancy, predominantly feeding difficulties $(13.8$ per cent.), and respiratory diseases, almost exclusively infections $(13 \cdot 3$ per cent.).

Place of Delivery.-Table II shows that the in-patient morbidity of babies delivered at home (3.2 per cent.) was almost identical to that of those delivered in hospital (3.5 per cent.). This is sur-

\section{TABLE I}

PRINCIPAL DIAGNOSIS OF FIRST SPELL IN HOSPITAL IN PRI BABIES BORN IN 1962 WHO WERE SUBSEQUENTLY DISCHARGED FROM HOSPITAL AT LEAST ONCE IN THE SAME YEAR

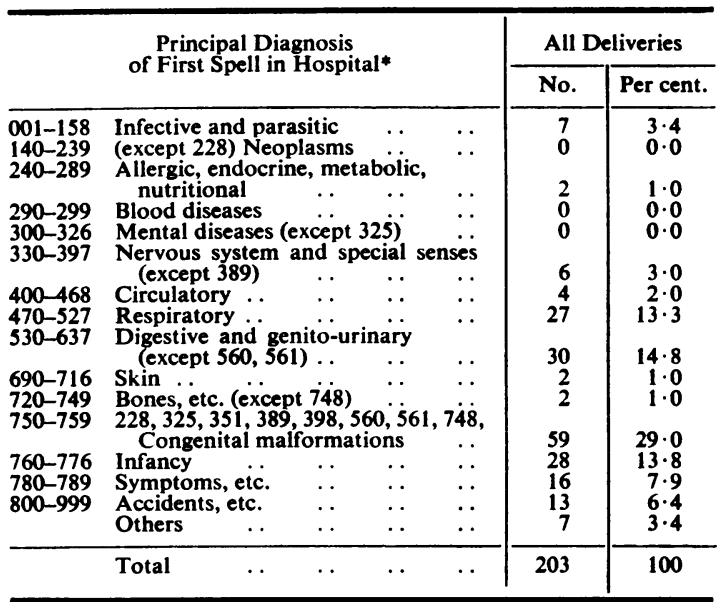

* Bracketed figures in this Table and in Table III refer to the diagnostic rubrics of the International Statistical Classification of Diseases, Injuries, and Causes of Death (7th revision).

TABLE II

IN-PATIENT MORBIDITY OF THE BABY IN 1962, BY PLACE OF DELIVERY

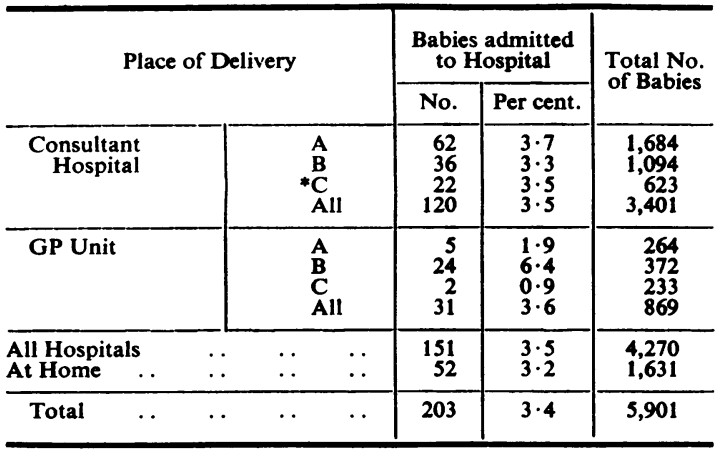

*A mixed consultant and GP Unit. prising in view of the selection in this area of difficult cases and of nulliparae and grand multiparae for delivery in hospital (Acheson and Evans, 1964). When all consultant obstetric units are compared with all GP obstetric units, the subsequent morbidity of the baby in the two groups is also closely similar; however, within general practitioner units as a group there is substantial variation. Thus for baibies born at GP unit B the subsequent morbidity was 6.4 per cent., while for GP units A and $C$ the figures are 1.9 per cent. and 0.9 per cent. respectively. It seems likely that GP unit B's high figure is due in part at least to the presence in the same town of hospital beds for children under the control of GPs.

Although the numbers are small, the in-patient morbidity in four diagnostic groups has been compared for hospital and home deliveries in Table III. The discharge rate for congenital malformations, and for nutritional maladjustment, etc., was similar in the two groups, but was slightly higher for infections in babies delivered in hospital than in those delivered at home. This was compensated for by a higher rate for miscellaneous causes among babies delivered at home, than among those delivered in hospital.

\section{TABLE III}

BABIES DISCHARGED FROM HOSPITAL ONCE OR MORE AND IN-PATIENT MORBIDITY PER CENT. IN FOUR DIAGNOSTIC GROUPS, BY PLACE OF DELIVERY

\begin{tabular}{|c|c|c|c|c|}
\hline \multirow{3}{*}{ Diagnostic Group } & \multicolumn{4}{|c|}{ Place of Delivery } \\
\hline & \multicolumn{2}{|c|}{ Hospital } & \multicolumn{2}{|c|}{ Home } \\
\hline & No. & $\begin{array}{l}\text { In-patient } \\
\text { Morbidity } \\
\text { Per cent. }\end{array}$ & No. & $\begin{array}{l}\text { In-patient } \\
\text { Morbidity } \\
\text { Per cent. }\end{array}$ \\
\hline 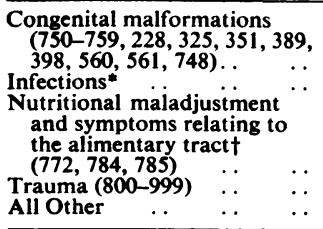 & $\begin{array}{r}16 \\
8 \\
42\end{array}$ & $\begin{array}{l}0.4 \\
0 \cdot 2 \\
1 \cdot 0\end{array}$ & $\begin{array}{r}4 \\
5 \\
19\end{array}$ & $\begin{array}{l}0.9 \\
0.6 \\
\\
0.2 \\
0.3 \\
1.2\end{array}$ \\
\hline Total & 151 & $3 \cdot 5$ & 52 & $3 \cdot 2$ \\
\hline
\end{tabular}

*001-138, 470-502, 571, 763-768, and miscellaneous infections coded elsewhere.

†Excludes diarrhoea in infancy.

Plurality.-136 babies of multiple births survived delivery and were discharged alive. In this group, as might be expected, the subsequent hospital morbidity was higher $(6.6$ per cent.) than in singletons $(3 \cdot 4$ per cent.), but the difference is not significant. 

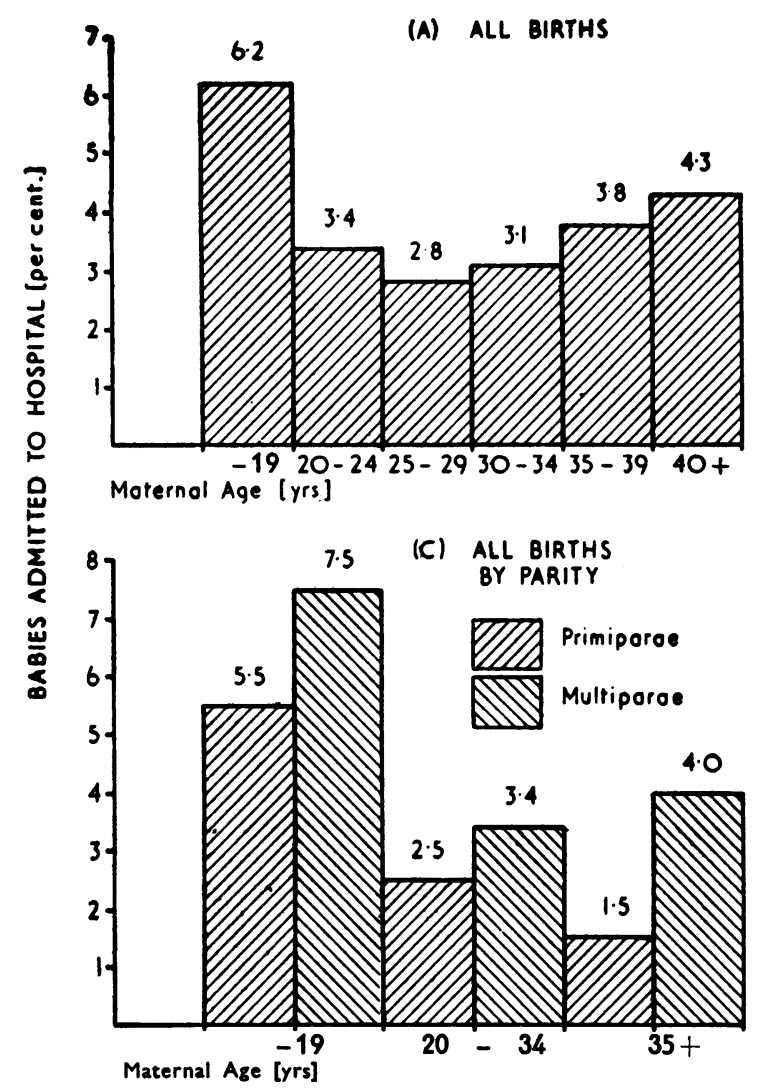

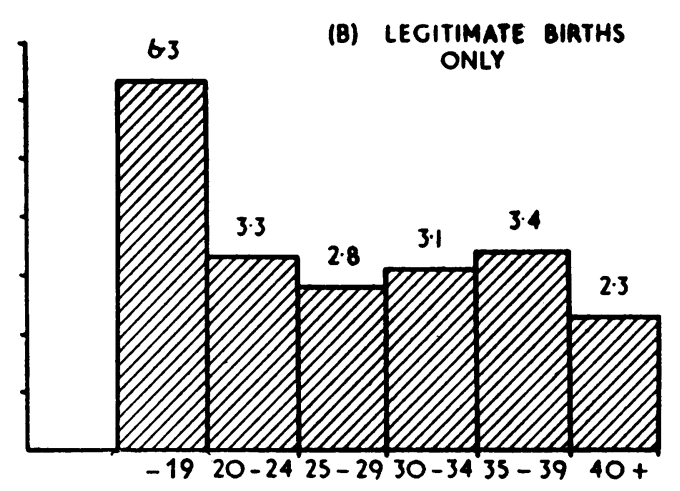

(D) ALL PIRTHS BY

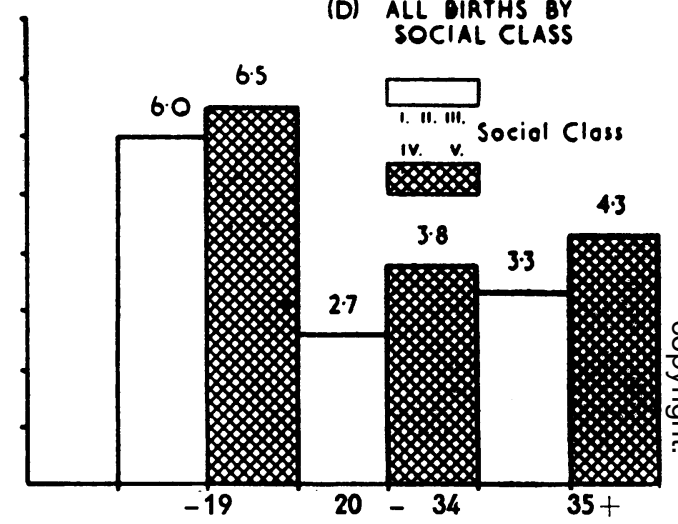

Fig. 1.-In-patient morbidity of the baby in 1962, according to maternal age: $(A)$ all births; $(B)$ legitimate births only; $(C)$ all births, nulliparae and multiparae separately; $(D)$ all births, social class I II, and III, and IV and V separately.

MATERNAL FACTORS

Maternal Age.-The in-patient morbidity of the babies is given by maternal age at time of delivery in Table IV and Fig. 1. It is highest (6.2 per cent.) in babies of mothers under age 20 , after which it falls, reaching a minimum of 2.8 per cent. in the 25 to 29-year age group, with a slight increase

TABLE IV

IN-PATIENT MORBIDITY OF THE BABY IN 1962, BY MATER NAL AGE

\begin{tabular}{c|c|c|c}
\hline $\begin{array}{c}\text { Maternal Age at } \\
\text { Time of Delivery } \\
\text { (yrs) }\end{array}$ & \multicolumn{2}{|c|}{$\begin{array}{c}\text { Babies Discharged } \\
\text { from Hospital }\end{array}$} & $\begin{array}{c}\text { Total No. } \\
\text { of Babies }\end{array}$ \\
\cline { 2 - 4 } & No. & Per cent. & \\
\hline 19 or Under & 30 & $6 \cdot 2$ & 487 \\
$20-24$ & 65 & $3 \cdot 4$ & 1,928 \\
$25-29$ & 49 & $2 \cdot 8$ & 1,739 \\
$30-34$ & 33 & $3 \cdot 1$ & 1,078 \\
35 or Over & 26 & $3 \cdot 9$ & 663 \\
Not Known & - & - & 6 \\
\hline Total.. & 203 & $3 \cdot 4$ & 5,901 \\
\hline
\end{tabular}

thereafter. When illegitimate births were excluded, the excess morbidity in the babies of young mothers remained unaltered (Fig. 1B), but the secondary rise in the babies of mothers over age 30 seen in Fig. 1A disappeared. The difference in morbidity between the babies of mothers in the youngest age group and the remainder is significant $(t=2.7 ; \mathrm{P}<0.01)$. The findings were similar when babies delivered at home and in hospital were considered separately.

Figure 1C shows the effect of maternal age in nulliparae and multiparae separately and demonstrates that babies of young mothers have a high hospital morbidity in each of these groups. A similar analysis, taking into account social class of mother, shows that when Classes I, II, and III and Classes IV and V are grouped* the hospital morbidity in each is highest in young mothers (Fig. 1D).

*The armed forces, students, and unclassified cases were excluded. 


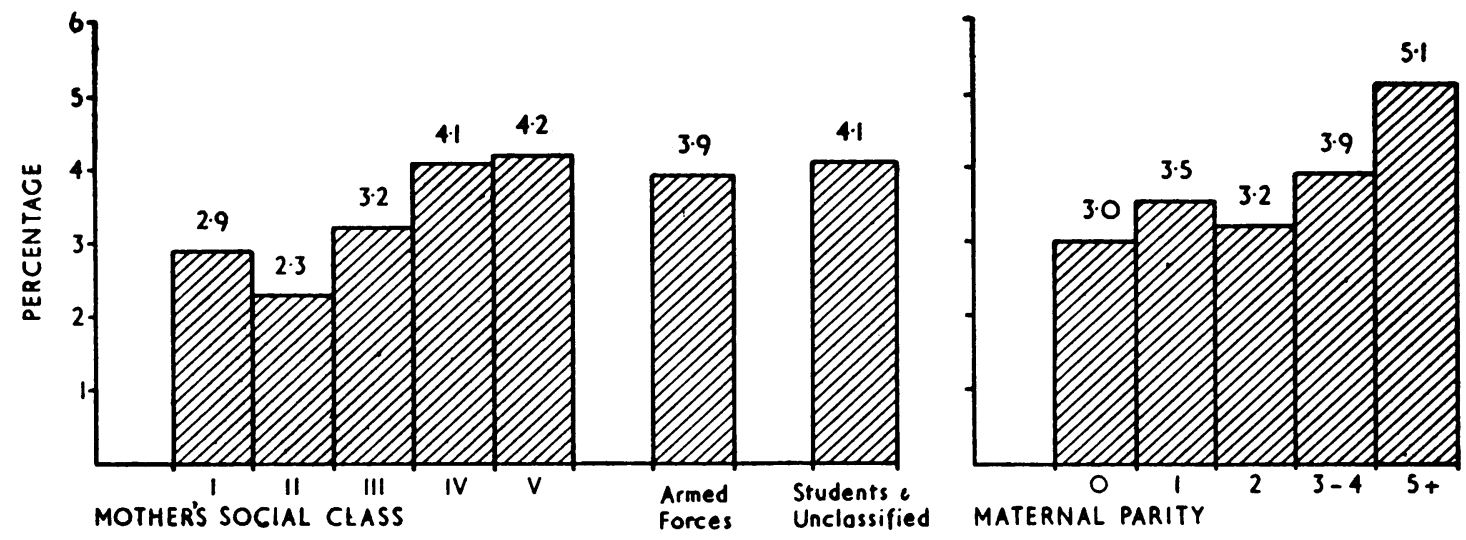

FIG. 2.-In-patient morbidity of the baby in 1962 , according to parental social class and parity.

Parity.-Table $\mathrm{V}$ and Fig. 2 show the in-patient morbidity of the babies by parity. A slight trend of increasing morbidity with increasing parity is visible but this is not significant. The result taken in conjunction with Figs $1 \mathrm{~A}$ and $\mathrm{B}$ suggests that parity is less important than maternal

TABLE V

IN-PATIENT MORBIDITY OF THE BABY IN 1962 , BY MATERNAL PARITY

\begin{tabular}{l|c|c|c}
\hline \multirow{2}{*}{ Maternal Parity } & \multicolumn{2}{|c|}{$\begin{array}{c}\text { Babies Discharged } \\
\text { from Hospital }\end{array}$} & $\begin{array}{c}\text { Total No. } \\
\text { of Babies }\end{array}$ \\
\cline { 2 - 3 } & No. & Per cent. & \\
\hline Nulliparae & 62 & $3 \cdot 0$ & 2,088 \\
1 & 62 & $3 \cdot 5$ & 1,753 \\
2 & 34 & $3 \cdot 2$ & 1,058 \\
3 and 4 & 28 & $3 \cdot 9$ & 709 \\
5or Over & 14 & $5 \cdot 1$ & 274 \\
Not Known & 3 & 19 \\
\hline Total .. & 203 & $3 \cdot 4$ & 5,901 \\
\hline
\end{tabular}

age in relation to the early hospital morbidity of the baby. Hospital and home deliveries considered separately show almost identical trends.

Social Class.-Table VI and Fig. 2 depict the in-patient morbidity by parental social class, derived from the father's occupation as given on the birth certificate. When all cases are considered together, an increasing trend of morbidity with diminishing social class is seen, which does not quite reach the conventional limit of statistical significance. (When Armed Forces, students, and unclassified cases are excluded $\chi^{2}=5.5$; d.f. $=2 ; \mathrm{P}<0.1>0.05$ ). This trend is slightly more marked for home deliveries considered alone $\left(\chi^{2}=6.6 ;\right.$ d.f. $=2 ; \mathrm{P}<0.05>$ 0.01 ), and less marked for hospital deliveries alone.

Maternal Past History of Stillbirthor Miscarriage.Table VII (overleaf) shows that a past history of

TABLE VI

EFFECT OF MATERNAL SOCIAL CLASS ON IN-PATIENT MORBIDITY OF THE BABY IN 1962

\begin{tabular}{|c|c|c|c|c|c|c|c|c|c|c|c|}
\hline \multirow{3}{*}{\multicolumn{3}{|c|}{$\underset{\text { Social Class* }}{\text { Maternal }}$}} & \multicolumn{3}{|c|}{ All Cases } & \multicolumn{3}{|c|}{ Home Deliveries } & \multicolumn{3}{|c|}{ Hospital Deliveries } \\
\hline & & & \multicolumn{2}{|c|}{$\begin{array}{l}\text { Babies Discharged } \\
\text { from Hospital }\end{array}$} & \multirow{2}{*}{$\begin{array}{l}\text { Total No. } \\
\text { of Babies }\end{array}$} & \multicolumn{2}{|c|}{$\begin{array}{l}\text { Babies Discharged } \\
\text { from Hospital }\end{array}$} & \multirow{2}{*}{$\begin{array}{l}\text { Total No. } \\
\text { of Babies }\end{array}$} & \multicolumn{2}{|c|}{$\begin{array}{l}\text { Babies Discharged } \\
\text { from Hospital }\end{array}$} & \multirow{2}{*}{$\begin{array}{l}\text { Total No. } \\
\text { of Babies }\end{array}$} \\
\hline & & & No. & Per cent. & & No. & Per cent. & & No. & Per cent. & \\
\hline $\begin{array}{l}\text { Class I } \\
\text { Class II }\end{array}$ & $\therefore$ & $\therefore$ & 13 & $\begin{array}{l}2 \cdot 9 \\
2 \cdot 3\end{array}$ & $\left.\begin{array}{l}450 \\
564\end{array}\right\}$ & 3 & $1 \cdot 3$ & 232 & 23 & $2 \cdot 9$ & 782 \\
\hline Class III & $\ldots$ & $\ldots$ & 80 & $3 \cdot 2$ & 2,466 & 17 & $2 \cdot 5$ & 685 & 63 & $3 \cdot 5$ & 1,781 \\
\hline $\begin{array}{l}\text { Class IV } \\
\text { Class V }\end{array}$ & $\begin{array}{l}\ldots \\
\ldots\end{array}$ & $\therefore$ & $\begin{array}{l}43 \\
26\end{array}$ & $\begin{array}{l}4 \cdot 1 \\
4 \cdot 2\end{array}$ & $\left.\begin{array}{r}1,047 \\
614\end{array}\right\}$ & 23 & $4 \cdot 4$ & 520 & 46 & $4 \cdot 0$ & 1,141 \\
\hline $\begin{array}{l}\text { Armed Forces } \\
\text { Students } \\
\text { Unclassified }\end{array}$ & $\because$ & $\begin{array}{l}\cdots \\
\cdots\end{array}$ & $\begin{array}{l}16 \\
0 \\
12\end{array}$ & $\begin{array}{l}3 \cdot 9 \\
0 \cdot 0 \\
4 \cdot 1\end{array}$ & $\left.\begin{array}{r}408 \\
63 \\
289\end{array}\right\}$ & 9 & $4 \cdot 6$ & 194 & 19 & $3 \cdot 4$ & 566 \\
\hline Total & $\ldots$ & . & 203 & $3 \cdot 4$ & 5,901 & 52 & $3 \cdot 2$ & 1,631 & 151 & $3 \cdot 5$ & 4,270 \\
\hline
\end{tabular}


TABLE VII

EFFECT OF A MATERNAL PAST HISTORY OF STILLBIRTH OR MISCARRIAGE ON IN-PATIENT MORBIDITY OF THE BABY IN 1962

\begin{tabular}{|c|c|c|c|}
\hline \multirow{2}{*}{$\begin{array}{l}\text { Maternal Past History of } \\
\text { Stillbirth or Miscarriage }\end{array}$} & \multicolumn{2}{|c|}{$\begin{array}{l}\text { Babies Discharged } \\
\text { from Hospital }\end{array}$} & \multirow{2}{*}{$\begin{array}{l}\text { Total No. } \\
\text { of Babies }\end{array}$} \\
\hline & No. & Per cent. & \\
\hline $\begin{array}{l}\text { No Stillbirths or Miscarriages } \\
1,2,3 \text {, or More Stillbirths } \\
1,2,3 \text {, or More Miscarriages } \\
1 \text { or more Stillbirths and } \\
1 \text { or More Miscarriages } \\
\text { Not Known or Not Stated }\end{array}$ & $\begin{array}{r}165 \\
4 \\
32 \\
0 \\
2\end{array}$ & $\begin{array}{l}3 \cdot 3 \\
3 \cdot 0 \\
4 \cdot 4 \\
0 \cdot 0 \\
5 \cdot 9\end{array}$ & $\begin{array}{r}4,981 \\
135 \\
729 \\
\\
20 \\
34\end{array}$ \\
\hline Total .. & 203 & $3 \cdot 4$ & 5,899 \\
\hline
\end{tabular}

maternal miscarriage or stillbirth did not appear to influence the in-patient morbidity of the baby in the early months. The relationship of these factors was also examined separately in babies of mothers under or over 20 years of age, but no trends were seen.

Legitimacy. - 256 babies who survived delivery and were discharged from hospital alive were known to be illegitimate. This almost certainly underestimates the true state of affairs as our means of ascertainment of legitimacy was inadequate in 1962. The in-patient morbidity in this group was 5.9 per cent. as opposed to 3.3 per cent in the legitimate group, but the difference is not significant. When classified by maternal age, the morbidity rate of the illegitimate babies was similar throughout the age range (see Figs $1 \mathrm{~A}$ and $\mathrm{B}$ ).

Maternal Blood Group.-This was recorded in all but $393(6.7$ per cent.) of the cases. There is no definite indication of any relationship between maternal blood group and subsequent in-patient morbidity for the $\mathrm{A}, \mathrm{B}, \mathrm{O}$, or Rhesus factors (Table VIII).

TABLE VIII

IN-PATIENT MORBIDITY OF THE BABY IN 1962, BY MATERNAL BLOOD GROUP

\begin{tabular}{|c|c|c|c|}
\hline \multirow{2}{*}{$\begin{array}{l}\text { Maternal } \\
\text { Blood Group }\end{array}$} & \multicolumn{2}{|c|}{$\begin{array}{l}\text { Babies Discharged } \\
\text { from Hospital }\end{array}$} & \multirow{2}{*}{$\begin{array}{l}\text { Total No. } \\
\text { of Babies }\end{array}$} \\
\hline & No. & Per cent. & \\
\hline $\begin{array}{l}\mathbf{A} \\
\mathbf{A B} \\
\mathbf{O} \\
\mathbf{B} \\
\text { Not Known }\end{array}$ & $\begin{array}{r}80 \\
2 \\
91 \\
15 \\
15\end{array}$ & $\begin{array}{l}3 \cdot 3 \\
1 \cdot 3 \\
3 \cdot 7 \\
3 \cdot 2 \\
3 \cdot 8\end{array}$ & $\begin{array}{r}2,442 \\
155 \\
2,441 \\
470 \\
393\end{array}$ \\
\hline Total $\quad \ldots \quad \ldots$ & 203 & $3 \cdot 4$ & 5,901 \\
\hline $\begin{array}{l}\text { Rhesus + } \\
\text { Rhesus - } \\
\text { Not Known }\end{array}$ & $\begin{array}{r}153 \\
35 \\
15\end{array}$ & $\begin{array}{l}3 \cdot 4 \\
3 \cdot 5 \\
3 \cdot 8\end{array}$ & $\begin{array}{r}4,503 \\
1,005 \\
393\end{array}$ \\
\hline Total $\ldots$ & 203 & $3 \cdot 4$ & 5,901 \\
\hline
\end{tabular}

Obstetric FACtors and FaCtORS RELATING TO THE BABY

Birthweight.-The influence of birthweight on the in-patient morbidity is shown in Table IX and Fig. 3. As might be expected, babies weighing less than $5 \frac{1}{2} \mathrm{lb}$. $(2,490$ g.) who survive the perinatal period have a significantly higher in-patient morbidity

TABLE IX

EFFECT OF BIRTHWEIGHT ON IN-PATIENT MORBIDITY OF THE BABY IN 1962

\begin{tabular}{c|c|c|c}
\hline $\begin{array}{c}\text { Baby's } \\
\text { Birth Weight } \\
\text { (lb.) }\end{array}$ & \multicolumn{2}{|c|}{$\begin{array}{c}\text { Babies Discharged } \\
\text { from Hospital }\end{array}$} & $\begin{array}{c}\text { Total No. } \\
\text { of Babies }\end{array}$ \\
\cline { 2 - 3 } & No. & Per cent. & \\
\hline$-4 \frac{1}{2}$ & 8 & $9 \cdot 2$ & 87 \\
$-5 \frac{1}{2}$ & 13 & $6 \cdot 0$ & 217 \\
-6.7 & 39 & $4 \cdot 5$ & 866 \\
$-7 \frac{1}{2}$ & 66 & $3 \cdot 3$ & 1,975 \\
-9 & 34 & $3 \cdot 3$ & 1,041 \\
-10 & 29 & $2 \cdot 3$ & 1,249 \\
10 or More & 9 & $2 \cdot 5$ & 354 \\
Not Weighed & 1 & $4 \cdot 4$ & 90 \\
\hline Total & 1 & $4 \cdot 5$ & 22 \\
\hline
\end{tabular}
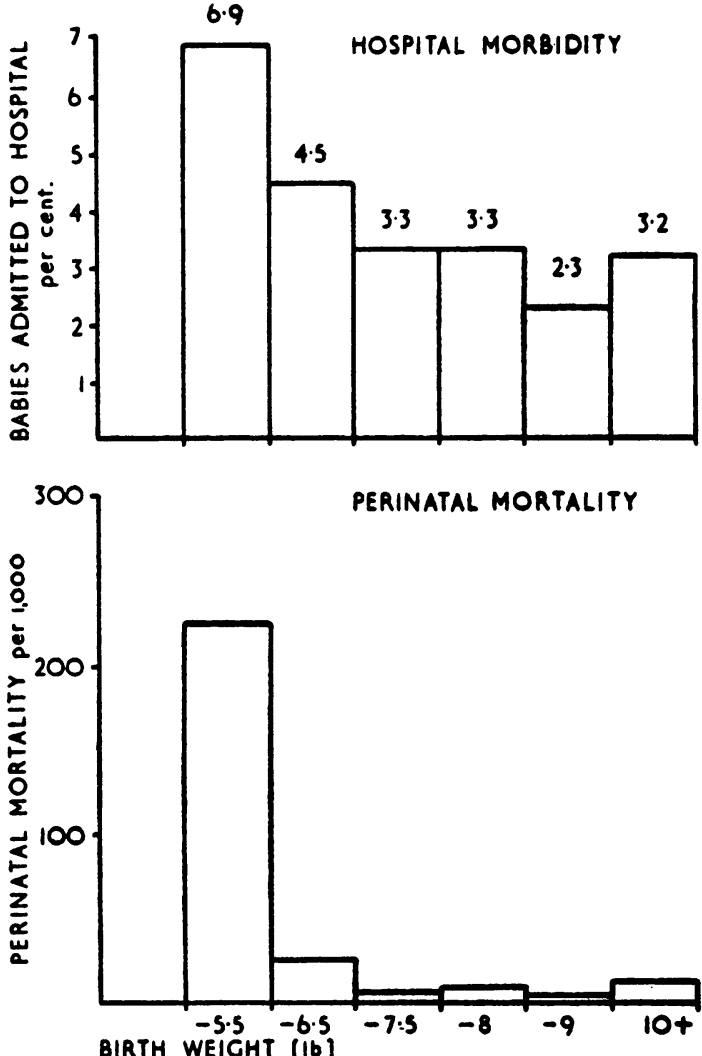

FIG. 3.-In-patient morbidity and perinatal mortality in 1962, by birthweight. 
than the remainder $(t=2.4 ; \mathrm{P}<0.05)$. For weights higher than $5 \frac{1}{2} \mathrm{lb}$. the in-patient morbidity declines to a minimum of $2 \cdot 3$ per cent. in the $8-9 \mathrm{lb}$. group with a slight rise thereafter. It is interesting that the lowest morbidity figure should be for babies with weights higher than both the median $(6.9 \mathrm{lb}$.) and the average $(7.5 \mathrm{lb}$.). A similar trend is shown for perinatal mortality taken from the same material (ORLS area, 1962). It seems therefore that the average birthweight may not be the optimal (Karn and Penrose, 1951).

Type of Delivery.-This was classified according to the International Classification into the following groups:

1. Spontaneous (a) Uncomplicated.

(b) Complicated.

2. Manipulation without instruments.

3. Forceps delivery (all types).

4. Caesarean section.

5. Unassisted.

6. All other (including vacuum delivery).

Uncomplicated spontaneous deliveries are followed by a hospital morbidity ( $3 \cdot 3$ per cent.) very close to the average (Table $\mathrm{X}$ ). Of the remainder the small group of unassisted spontaneous deliveries has the highest morbidity. It is interesting that after forceps delivery and Caesarean section the morbidity is less than average. Further analysis, taking into account birthweight, maternal age, and type of morbidity, will be undertaken when further material is available.

TABLE X

IN-PATIENT MORBIDITY OF THE BABY IN 1962, BY TYPE OF DELIVERY

\begin{tabular}{|c|c|c|c|}
\hline \multirow[t]{2}{*}{ Type of Delivery } & \multicolumn{2}{|c|}{$\begin{array}{l}\text { Babies Discharged } \\
\text { from Hospital }\end{array}$} & \multirow{2}{*}{$\begin{array}{l}\text { Total No. } \\
\text { of Babies }\end{array}$} \\
\hline & No. & Per cent. & \\
\hline 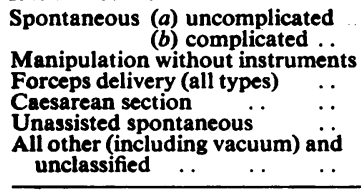 & $\begin{array}{r}134 \\
34 \\
4 \\
20 \\
3 \\
6 \\
2 \\
\end{array}$ & $\begin{array}{r}3 \cdot 3 \\
4 \cdot 8 \\
5 \cdot 5 \\
2 \cdot 3 \\
1 \cdot 7 \\
10 \cdot 0 \\
9 \cdot 5 \\
\end{array}$ & $\begin{array}{r}4,017 \\
703 \\
73 \\
853 \\
174 \\
60 \\
21 \\
\end{array}$ \\
\hline Total .. & 203 & $3 \cdot 4$ & 5,901 \\
\hline
\end{tabular}

Length of Second Stage of Labour.-In 1962 an attempt was made to determine the length of the second stage of labour from the obstetric records, as it was felt that this might provide an index of foetal stress. Table XI shows that, when all cases (excluding 173 Caesarean sections) are considered, there is no clear evidence of any relationship between the two variables. Removal of small babies (weighing
TABLE XI

IN-PATIENT MORBIDITY OF THE BABY IN 1962 , BY LENGTH OF SECOND STAGE OF LABOUR

\begin{tabular}{|c|c|c|c|}
\hline \multirow{2}{*}{$\begin{array}{l}\text { Length of Second } \\
\text { Stage of Labour } \\
\text { (min.) }\end{array}$} & \multicolumn{2}{|c|}{$\begin{array}{l}\text { Babies Discharged } \\
\text { from Hospital }\end{array}$} & \multirow{2}{*}{$\begin{array}{l}\text { Total No. } \\
\text { of Babies }\end{array}$} \\
\hline & No. & Per cent. & \\
\hline $\begin{array}{l}-30 \\
-\quad 60 \\
\text { More than } 60 \\
\text { Not Applicable } \\
\text { (Caesarean section) } \\
\text { or Not Known }\end{array}$ & $\begin{array}{r}130 \\
37 \\
16 \\
\\
20\end{array}$ & $\begin{array}{l}3 \cdot 7 \\
3.4 \\
2.6 \\
3 \cdot 0\end{array}$ & $\begin{array}{r}3,538 \\
1,084 \\
622 \\
\\
657\end{array}$ \\
\hline Total $\ldots$ & 203 & $3 \cdot 4$ & 5,901 \\
\hline
\end{tabular}

less than $5 \frac{1}{2} \mathrm{lb}$.) from the analysis did not affect the issue. The second stage of labour is notably difficult to define and to measure, and it is possible that the negative result is an indication of this.

Maternal Anaesthesia.-In Table XII the babies are classified according to whether an anaesthetic was administered to the mother for the delivery; the type of anaesthesia is also given. The results are negative. It is particularly interesting that the substantial number of babies whose mothers had a general or spinal anaesthetic have a similar hospital morbidity experience to those whose mothers had no anaesthetic.

TABLE XII

IN-PATIENT MORBIDITY OF THE BABY IN 1962, BY NATURE OF ANAESTHETIC ADMINISTERED TO MOTHER AT DELIVERY*

\begin{tabular}{|c|c|c|c|c|c|c|}
\hline \multirow{2}{*}{\multicolumn{4}{|c|}{$\begin{array}{l}\text { Anaesthetic Administered } \\
\text { to Mother at Delivery }\end{array}$}} & \multicolumn{2}{|c|}{$\begin{array}{l}\text { Babies Discharged } \\
\text { from Hospital }\end{array}$} & \multirow{2}{*}{$\begin{array}{l}\text { Total No. } \\
\text { of Babies }\end{array}$} \\
\hline & & & & No. & Per cent. & \\
\hline $\begin{array}{l}\text { None } \\
\text { General } \\
\text { Spinal } \\
\text { Local } \\
\text { Pudendal } \\
\text { Unknown }\end{array}$ & $\begin{array}{l}\ldots \\
\ddot{*} \\
\ddot{*} \\
\cdots\end{array}$ & $\begin{array}{l}\ldots \\
\ddot{*} \\
\ddot{*} \\
\ddot{*}\end{array}$ & $\begin{array}{l}\ldots \\
\cdots \\
\cdots \\
\cdots\end{array}$ & $\begin{array}{r}113 \\
8 \\
9 \\
2 \\
10 \\
9\end{array}$ & $\begin{array}{l}3 \cdot 6 \\
2 \cdot 6 \\
3 \cdot 4 \\
2 \cdot 5 \\
2 \cdot 5 \\
9 \cdot 7\end{array}$ & $\begin{array}{r}3,124 \\
306 \\
263 \\
79 \\
405 \\
93\end{array}$ \\
\hline Total & . & $\ldots$ & . & 151 & $3 \cdot 5$ & 4,270 \\
\hline
\end{tabular}

*Combination of local or pudendal not done.

Administration of Oxygen to the Infant at Birth.-A record of the administration of oxygen to the infant was found in 381 cases (6.4 per cent.), of which almost all (370) were delivered in hospital. As the administration of oxygen might be expected to correlate with the existence of asphyxia at birth, it was interesting and unexpected to find that the subsequent morbidity was identical ( $3 \cdot 4$ per cent.) whether or not oxygen was given.

Baby's Blood Group.-Blood derived from the umbilical cord had been typed in respect of the ABO and Rhesus factors in 1,361 babies who survived 
delivery and discharge from hospital. The subsequent in-patient morbidity in each of the four ABO phenotypes is shown in Table XIII. No significant differences were demonstrated. The Rhesus positive and negative groups are given in Table XIII; there was no material difference in morbidity between these two groups.

TABLE XIII

IN-PATIENT MORBIDITY OF THE BABY IN 1962 , BY BABY'S BLOOD GROUP

\begin{tabular}{|c|c|c|c|c|}
\hline \multirow{2}{*}{\multicolumn{2}{|c|}{$\begin{array}{c}\text { Baby's } \\
\text { Blood Group }\end{array}$}} & \multicolumn{2}{|c|}{$\begin{array}{l}\text { Babies Discharged } \\
\text { from Hospital }\end{array}$} & \multirow{3}{*}{$\begin{array}{r}\begin{array}{r}\text { Total No } \\
\text { of Babies }\end{array} \\
608 \\
39 \\
603 \\
111 \\
2,909\end{array}$} \\
\hline & & \multirow{2}{*}{$\begin{array}{r}\text { No. } \\
19 \\
3 \\
18 \\
3 \\
108\end{array}$} & \multirow{2}{*}{$\begin{array}{c}\text { Per cent. } \\
3 \cdot 1 \\
7.7 \\
3.0 \\
2.7 \\
3.7\end{array}$} & \\
\hline $\begin{array}{ll}\mathbf{A} & \ldots \\
\mathbf{A B} & \cdots \\
\mathbf{O} & \cdots \\
\text { Bnclassified }\end{array}$ & $\begin{array}{l}. \\
\because \\
\therefore\end{array}$ & & & \\
\hline Total $\ldots$ & .. & 151 & $3 \cdot 5$ & 4,270 \\
\hline $\begin{array}{l}\text { Rhesus +.. } \\
\text { Rhesus }-. . \\
\text { Unclassified }\end{array}$ & $\begin{array}{l}. \\
\because\end{array}$ & $\begin{array}{r}33 \\
10 \\
108\end{array}$ & $\begin{array}{l}3 \cdot 0 \\
4 \cdot 0 \\
3 \cdot 7\end{array}$ & $\begin{array}{l}1,111 \\
250 \\
2,909\end{array}$ \\
\hline Total & .. & 151 & $3 \cdot 5$ & 4,270 \\
\hline
\end{tabular}

Factors associated WITH DOMICILIARy Deliveries

Type of Assistance at Delivery.-A general practitioner was present at $430(26.4$ per cent.) of the deliveries which took place at home. The subsequent morbidity of these babies $(3 \cdot 2$ percent.) was identical to that of those babies at whose delivery a midwife was the senior person present. Babies whose mothers had no assistance at delivery had a higher subsequent morbidity ( $7 \cdot 3$ per cent.) but the number was small and the difference from the remainder is not significant (Table XIV).

TABLE XIV

IN-PATIENT MORBIDITY OF THE BABY IN 1962, BY NATURE OF ASSISTANCE AT DELIVERY (DOMICILIARY)

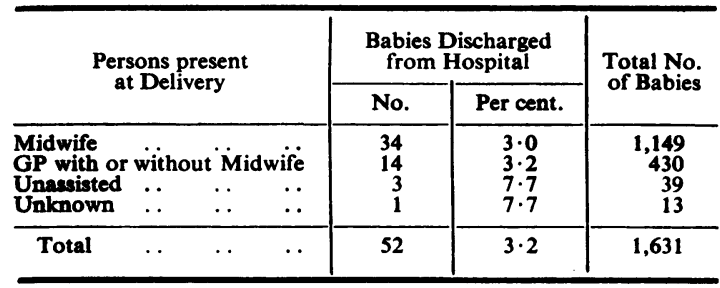

Week in Pregnancy of Midwife's First Antenatal Visit.-For mothers booked and delivered at home, a striking relationship was demonstrated between the week of gestation in which the first antenatal visit of the midwife took place and the subsequent hospital morbidity of the baby after delivery (Table
$X V$ and Fig. 4). This trend is significant $\left(\chi^{2}=9 \cdot 6\right.$; d.f. $=2 ; \mathrm{P}<0.01$ ). It was thought at first that the trend might be due to a bias introduced by the absence from the Table of 143 mothers booked for confinement at home but later transferred for delivery in hospital. However, the subsequent morbidity of the babies of these mothers (not shown) was only slightly higher than average ( $4 \cdot 2$ per cent.) and could not have affected the issue. It seems possible that the relationship between the date of the first antenatal visit and subsequent morbidity may indicate that mothers who seek medical aid late in pregnancy are in general those who later have difficulty in caring for the baby.

TABLE XV

IN-PATIENT MORBIDITY OF THE BABY IN 1962 , BY DATE OF MIDWIFE'S FIRST ANTENATAL VISIT DURING MOTHER'S PREGNANCY

\begin{tabular}{c|c|c|c}
\hline $\begin{array}{c}\text { Week in Pregnancy of } \\
\text { Midwife's First } \\
\text { Antenatal Visit }\end{array}$ & $\begin{array}{c}\text { Babies Discharged } \\
\text { from Hospital }\end{array}$ & $\begin{array}{c}\text { Total No. } \\
\text { of Babies }\end{array}$ \\
\cline { 2 - 3 } & No. & Per cent. & \\
\hline $\begin{array}{c}-19 \\
20-24\end{array}$ & 10 & $1 \cdot 4$ & 706 \\
$25-29$ & 12 & $3 \cdot 3$ & 360 \\
$30-34$ & 8 & $3 \cdot 2$ & 251 \\
$35+$ & 13 & $6 \cdot 6$ & 196 \\
No Visit or Not Known & 7 & $8 \cdot 5$ & 82 \\
\hline Total & 2 & $5 \cdot 6$ & 36 \\
\hline
\end{tabular}

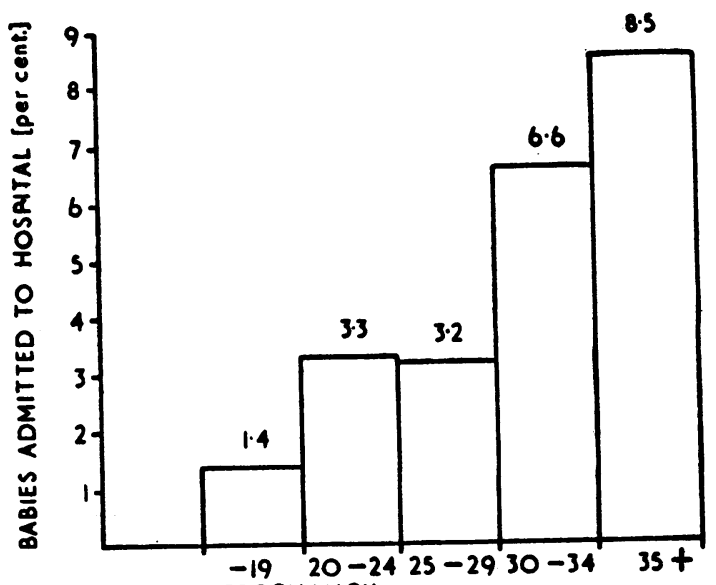

WEEK IN PRECNANCY

FIo. 4.-Relationship of the week in pregnancy of midwife's first antenatal visit to subsequent in-patient morbidity of the baby in 1962.

\section{Discussion}

The index of the babies' morbidity experience used here is a crude and defective one because it relates only to that fraction of illness which is treated in hospital. The size of this fraction depends 
not only upon the nature and severity of the illness but upon the social circumstances of the family, the policy of the general practitioner, and the availability of paediatric hospital beds. The variety of disease covered is wide and ranges from the extreme instance of conditions which would compel admission in any circumstances (e.g. meningitis, pyloric stenosis, strangulated hernia, meningocele) to those in which the decision that hospital treatment is warranted must largely depend upon other factors (e.g. feeding difficulties, chickenpox, redundant prepuce, bronchitis). Under these circumstances few, if any, clear-cut results can be expected. However, the Tables given here may form a useful basis for further analysis when a second and third year's data are available.

The finding that babies delivered at home had a similar total in-patient morbidity $(3 \cdot 2$ per cent.) to those delivered in hospital ( $3 \cdot 5$ per cent.) came as a surprise. To see to what extent this was due to the special instance of a small town where paediatric beds are under the control of GPs, babies born in the town and in the local authority area surrounding it were excluded. For the remainder, the morbidity figures are 2.8 per cent. for hospital deliveries and $3 \cdot 1$ per cent. for home deliveries, so that this exclusion results in the remaining babies delivered at home actually having a higher in-patient morbidity than those delivered in hospital. This finding is of particular interest in view of the fact that mothers are selected for delivery in hospital in terms of many factors which might be regarded $a$ priori as unfavourable to the infant. Using as a baseline the overall proportion of hospital deliveries of 73 per cent., the degree of selection for hospital confinement in terms of maternal age, legitimacy, and birthweight (all found to be important in this analysis) was as follows: the proportion of mothers under 20 years of age delivered in hospital was 86 per cent., of illegitimate births 91 per cent., and of babies less than $5 \frac{1}{2} \mathrm{lb}$. 85 per cent. In other words, if hospital and home confinements were standardized for these factors, the total in-patient morbidity of babies delivered at home would have been substantially higher than for babies born in hospital. Such a finding might be due to one or both of two possibilities:

(1) That babies delivered at home are less healthy than those delivered in hospital;

(2) That their utilization of in-patient beds is higher:

(a) because of social and family factors (e.g. these mothers are less able to look after a sick child at home);

(b) because of a more liberal referral policy by the GP (here the policy of the GP would reflect his training and experience and the distance and availability of paediatric beds).

As far as the first possibility is concerned, a comparison of the various types of diagnoses reached in hospital and home deliveries was unrevealing (Table III). The in-patient morbidity rate was higher in hospital than in home deliveries for infections, and about the same for congenital malformations and for the mixed group which includes feeding difficulties and alimentary symptoms. For trauma it was slightly lower than in home deliveries, but the number of cases was very small. The morbidity due to miscellaneous causes is slightly higher in home-delivered than in hospital-delivered babies.

In Tables IV to VIII the total in-patient morbidity of the baby has been related to certain maternal characteristics, including age at delivery, parity, social class, legitimacy, and blood group. The morbidity has been shown to be substantially higher in babies of young mothers (under 20 years of age) than in the remainder, and this holds true for home and hospital births separately, for nulliparae and multiparae, and for Social Classes I and II, III, and IV and V separately. The difference also remains when illegitimate births are excluded. The numbers are as yet too small to permit more than very crude estimates of the relative contribution of these different factors. However, it seems that low maternal age may be more important than either high parity or low social class. Precise comparisons with the work of Morris and Heady (1955), Heady, Daly, and Morris (1955), Daly, Heady, and Morris (1955), and Heady, Stevens, Daly, and Morris (1955) on neonatal (first month) and post-natal (2nd to 12th month) mortality are not possible, as the material reported here contains a mixture of neonatal and postneonatal events. However, it is interesting that both low maternal age and high parity were found to be important in their material. As in their results, the additive nature of these two factors is seen in the babies of multiparae under 20 years of age (Fig. 1c) where the morbidity rate was $7 \cdot 5$ per cent. On the other hand, in the babies of women under 20 , social class makes little difference to morbidity (Fig. 1d). These trends carry the suggestion that maternal inexperience may be an important factor in relation to the morbidity of the baby and that for young mothers a second or third baby following close after the first is particularly at risk. The low morbidity experience of the first baby of a woman over the age of 35 (Fig. 1c, 1.5 per cent.) makes a striking contrast to that of the second or subsequent child of the teenager $(7 \cdot 5$ per cent.).

With the single exception of birthweight (Table IX and Fig. 3), no relationship was found between 
factors recorded at delivery and the subsequent morbidity of the baby in the early months. In babies whose birthweight was less than $5 \frac{1}{2} \mathrm{lb}$., the subsequent morbidity was significantly higher than average. Douglas (1953), in a prospective study of a cohort of births, was able to detect significantly higher mortality rates in this group up to the end of the fourth year of life. The suggestion from Fig. 3 that the average weight may not be optimal is interesting and will be studied further.

No striking relationships were demonstrated between the subsequent in-patient morbidity of the baby and type of delivery, maternal anaesthesia, length of the second stage of labour, and administration of oxygen to the baby at birth. It may be that, when sufficient numbers of cases are available to study separate classes of illness in the child (e.g. congenital malformations, respiratory infections, and so on), these analyses will prove more rewarding.

\section{SUMMARY}

(1) The in-patient hospital morbidity experience in the early months of life of 5,901 babies born in 1962 to mothers resident in the Oxford Record Linkage Study area has been examined in relation to certain maternal and foetal characteristics and events at delivery. As the period of study was the calendar year 1962, the average period of exposure of the babies to the risk of admission to hospital was approximately 6 months.

(2) 203 (3.4 per cent.) of the babies were discharged once or more during 1962, the largest single cause of admission being congenital malformation.

(3) The hospital morbidity of babies delivered at home (3.2 per cent.) was almost identical to that of those delivered in hospital ( 3.5 per cent.) in spite of the selection of difficult cases, nulliparae, and grand multiparae for delivery in hospital.

(4) Of the maternal characteristics studied (age, parity, social class, and past history of stillbirth and miscarriage), low maternal age had the most important influence on the subsequent hospital morbidity of the baby.

(5) Babies weighing less than $5 \frac{1}{2} \mathrm{lb}$. at birth have a significantly higher hospital morbidity than the remainder. The lowest morbidity rate was seen in babies weighing 8 to $9 \mathrm{lb}$.
(6) No definite correlations were found between type of delivery, length of the second stage of labour, type of maternal anaesthesia, or the administration of oxygen to the baby at birth, and the subsequent hospital morbidity (all causes) of the baby.

(7) For domiciliary deliveries there was a striking correlation between the week of gestation in which the first antenatal visit of the midwife took place and the subsequent morbidity of the baby.

\section{REFERENCES}

Acheson, E. D. (1964). Brit. J. prev. soc. Med., 18, 8.

-and Evans, J. G. (1964). Proc. roy. Soc. Med., 57, 269.

Daly, C., Heady, J. A., and Morris, J. N. (1955), Lancet, 1,445 .

Douglas, J. W. B., and Mogford, C. (1953). Brit. med. J., $1,748$.

Heady, J. A., Daly, C., and Morris, J. N. (1955). Lancet, 1,395

, Stevens, C. F., Daly, C., and Morris, J. N. (1955). Ibid., 1, 499 .

Karn, M. N., and Penrose, L. S. (1951). Ann. Eugen. (Lond.), 16, 147.

Morris, J. N., and Heady, J. A. (1955). Lancet, 1, 343.

Newcombe, H. B. (1964). Ann. hum. Genet. (Lond.), 27, 367.

, Kennedy, J. M., Axford, S. J., and James, A. P. (1959). Science, 130, 954.

W.H.O. (1957) "Manual of the International Statistical Classification of Diseases, Injuries, and Causes of Death", 7th revision. Geneva.

\section{APPENDIX A}

\section{Contents and Arrangement of SUMMARY CARD}

Col.

No. Information

1 Job No.

2-11 Baby's Identifying No.

12-13 Mother's address.

14-15 Mother's age (yrs).

16 Mother's social class.

17 Place of delivery.

18 Sex and plurality of baby.

19 Live or stillborn.

20 Maternal risk group.

21 Birthweight (lb.).

22 Legitimacy.

23-25 General Practitioner.

$26 X$ ray of mother during pregnancy.

27-34 Mother's diagnoses at delivery.

35 Mother's blood group.

36 Parity.

37 Length of second stage of labour.

38 Result.

39 Infant feeding.

40 Perinatal death code

41 Cause of death or stillbirth.

42 Past obstetric history.

43 Drugs to baby during delivery. 
Col.

No. Information

If a Hospital Delivery

44-46 Consultant.

47-48 Hospital.

49 Baby's blood group.

50 Anaesthetic.

51-52 Duration of stay (mother) in hospital.

53-56 Baby's diagnosis at birth.

\section{If a Domiciliary Delivery}

44 Total visits of midwife.

45 Flying squad.

46 Admitted before, during, or after labour.

47 Doctor or midwife present at delivery.

48-5n Date of midwife's first visit.

51 Blank.

$52 \mathrm{X}$ indicates domiciliary delivery.

53-56 Baby's diagnosis.
Col.

No. Information

If Baby has One or More Hospital Admissions

57 Number of admissions of baby in 1962.

58-59 Age of baby at first admission.

60-63 Diagnosis of first admission of baby.

64 Disposal of first admission of baby.

65-66 Duration of stay of first admission of baby.

67-68 Date of admission, month, and second digit of year.

69-71 Diagnosis on last admission of baby.

72 Source of admission

73 Disposal of last admission.

If Baby has Died

74-76 Date of death (month and year).

77-80 Cause of Death. 